\title{
DO LEARNING APPROACHES MATTER ON SETTING THE TIME SPENT FOR PRE-SERVICE TEACHERS?
}

\author{
Andri Zainal *, Gaffar Hafiz Sagala, Sondang Aida Silalahi \\ Universitas Negeri Medan, Medan, Indonesia \\ *e-mail: andrizainal@unimed.ac.id
}

\begin{abstract}
This study redefines the research model highlighting the learning approach to investigate the interaction of relevant constructs in the relationship between the learning time spent and academic performance. The subjects of this study were 86 final-year undergraduate students of the accounting education department who had passed the final teaching training program as one of the requirements to become an accounting teacher at the high school and vocational level. In general, time spent has a positive and significant effect on the overall academic performance of the respondents and student groups with the Deep Learning Approach (DLA) and Surface Learning Approach (SLA)'s peers. However, each learning approach has no moderating effect on the relationship between time spent and academic performances. On the other hand, this finding provides an interesting point of view regarding the absence of significant differences in the length of study duration in the two groups of students, which confirms the independence of student learning styles nowadays. Hence, they get more flexible autonomy in improving their academic performance. This research also found that the DLA student group has better academic performance than their SLA counterparts, a finding that is in line with the Social Cognitive Theory and previous research results.
\end{abstract}

Keywords: Deep-Learning Approach, Scientific Approach, Accounting Teacher

\section{INTRODUCTION}

The study related to the learning approach should be an interesting issue, especially in evaluating learning at any level of education in the 21 st century. The changing conditions of the era, with all its dynamics, require regulators to actualize learning formulas that are oriented towards optimizing learning outcomes and stimulating student competence. The embodiment of the learning approach is categorized into two dimensions: DLA and SLA (Beattie IV et al., 1997; Biggs, 1987; Gordon \& Debus, 2002; Hall et al., 2004). In particular, Hall et al. (2004) emphasized that students' conceptual and analytical skills will be optimally formed when DLA is practiced effectively into their learning style.

Everaert et al. (2017) highlighted the urgency of the DLA application in optimizing the understanding of Accounting lecture material to create students' conceptual and analytical competencies in relevant subjects. One of the important findings from the results of their study showed that the allocation of longer study time made a positive contribution to the implementation of DLA, which impacted the students' learning outcomes. Exploration of learning duration is one of the important points in this study, reflecting effective modeling of DLA applications in accounting learning at the college level. Thus, it can provide valuable input to regulators and lecturers specifically in formulating an effective DLA by controlling the learning duration factor, as Everaert et al. (2017) emphasized. On the other hand, the application of SLA founded negatively affects student learning outcomes which, in turn, limiting their expertise in memorizing and rewriting learning materials (Biggs et al., 2001; Everaert et al., 2017).

In the accounting education, which aims to prepare prospective accounting teachers, such a learning approach will provide a rich learning experience. With the experience of doing projects or mini-research, students can develop their critical thinking derived from the power of thinking and based on scientific foundations and debates that potentially occur during project and mini-research work (Bensley \& Murtagh, 2012; Blumenfeld et al., 1991; Reif, 1981; Sagala \& Effiyanti, 2019). This gives them a solid footing in decision-making and in developing problemsolving ideas (Dolmans et al., 2016; Korthagen, 2004; Reif, 1981). Thus, prospective teachers will have the power to think critically and logically to solve pedagogical problems and innovate their instructional designs when they become teachers. In a more dynamic and evolving teaching practice today, these skills will be more demanded. Therefore, the teacher education process is becoming increasingly needed to provide such a quality learning experience. 
Such learning practices are based on a constructivist approach (Bruner, 1996; Vygotsky, 1978). The constructivist approach seeks to design a learning environment in such a way as to be able to lead students to achieve their learning goals (Bada \& Olusegun, 2015; Bensley \& Murtagh, 2012; Pande \& Bharathi, 2020; Schunk, 2012). The learning environment in question is lighter literature, projects, group work, cooperative learning, cases, exercises, brainstorming, mini-research, and various other instruments whose outcome is the mastery of knowledge following predetermined standard qualifications (Bensley \& Murtagh, 2012; Christensen et al., 2019; Dolmans et al., 2016; Opdecam \& Everaert, 2018). In addition, the learning environment requires students to play an active role as both learners and practitioners. Such conditions provide opportunities for students to confirm their initial knowledge with the new knowledge they gain from fundamental theory, research results, and actual practice (Dejene et al., 2018; Dolmans et al., 2016; Sagala \& Effiyanti, 2019). This information then constructs a comprehensive understanding (Dunne \& Martin, 2006; Pande \& Bharathi, 2020; Scheer et al., 2012). Thus, students are projected to have new knowledge and learn experiences that teach them how to master new knowledge (Dolmans et al., 2016; Von Glasersfeld, 1998).

Interestingly, in responding to any instructional design implemented by the university, students have the autonomy to choose their own learning approach. It is because the learning approach has different drivers from the instructional approach. If the lecturer controls the instructional approach, the learning approach is controlled by the students themselves. Marton \& Säljö (1976) classify this approach to learning into two types: DLA and SLA. Biggs (1987) describes the SLA as an intention only to acquire sufficient knowledge, and it is used only to complete assignments or pass the exam. Meanwhile, the DLA is described as the intention that students instill from within themselves to commit to gain knowledge and understanding of the material indepth, so they will be able to think analytically and try to connect the knowledge gained with the knowledge previously acquired (Biggs, 1987; Biggs et al., 2001; Everaert et al., 2017; Hall et al., 2004). DLA is seen as making pre-service teachers experience a higher quality learning process than students with a surface learning approach (Chotitham et al., 2014; Gordon \& Debus, 2002). In addition, it will have implications for his capability as a teacher while on duty at school. However, the impact of DLA and SLA on the achievement of student academic performance still gives varied and inconsistent results (Dinsmore \& Alexander, 2012; Dolmans et al., 2016).

Theoretically, scientific-based learning such as Problem-Based Learning, Project-Based Learning, and Research-Based Learning can lead students to use a deep learning approach and, in turn, influencing student academic performance (Chotitham et al., 2014; Gordon \& Debus, 2002; Salamonson et al., 2013). However, several studies found that some students still practice surface learning even when the teacher applied the scientific learning method (Dolmans et al., 2016). Responding to those findings, researchers have debated that other variables may exist to increase the contrast between deep and surface learning. In addressing this limitation, Everaert et al. (2017) have examined motivation as a precedent of learning approaches and learning duration as a mediator of learning approaches on academic performance. In addition, Everaert et al. (2017) highlighted the urgency of the DLA application in optimizing the understanding of accounting lecture material to create students' conceptual and analytical competencies in relevant subjects. One of the important findings from the results of their study showed that the allocation of longer study time-spent made a positive contribution to the implementation of DLA, which impacted learning outcomes. However, the previous study does not yet analyze the interaction effect of DLA and learning time-spent to resulting better student performance.

Accordingly, responding to the competitiveness of knowledge that becomes more challenging and the need for higher-order thinking, the government of the Republic of Indonesia has updated the national education framework by issuing Presidential Regulation no. 8 of 2012 concerning the Indonesian National Qualifications Framework (IQF) and followed by the Minister of Education and Culture Regulation No. 73 of 2013 concerning the application of the IQF. The Government of the Republic of Indonesia developed this policy to respond to technological transformation and globalization, which urged changes in the competency posture that universities should produce. IQF is designed within the framework of competency tiers that integrates the complexity of attitudes, knowledge, and skills relevant to 21 st-century competencies that are increasingly needed in this competitive and global 
era. Graduates must master, manage, and create knowledge to solve actual problems in their work or business.

Following up on those expectations, the State University of Medan (in Bahasa: Universitas Negeri Medan-Unimed) has updated the curriculum and learning system. In this case, Unimed concentrates on improving the learning system through students' learning process and task formats. Unimed emphasizes student learning and assignments in critical journal reviews, critical book reviews, projects, mini-research, and idea engineering. The policy certainly refers to the implementation of scientific learning, problem-based learning, project-based learning, and research-based learning in higher education learning aimed at the formation of critical thinking, creative thinking, leadership skills, decisionmaking skills, and problem-solving skills (Bensley \& Murtagh, 2012; Reif, 1981). More specifically for the undergraduate students of accounting education of Unimed in the batch of 2016 as the subjects of the study; they experience both the initiation of curriculum based on the Indonesian IQF to remark the practice of the DLA since 2018 and the SLA's during the previous two years of the establishment of the ICQ based curriculum as mentioned earlier. Hence, the selection of the respondents' targets is fit to provide relevant information regarding the practices of DLA and SLA based on their recent experience.

In contrast to the study of Everaert et al. (2017), this study places learning time spent as a moderator in the relationship between students' learning approach and learning outcomes. In essence, the amount of learning duration is the domain of students, and they are free to determine how many hours they will use to study (Doumen et al., 2014). Therefore, the time consumed by each student will certainly vary even though they have the same learning approach orientation. However, Everaert et al. (2017) indicates that students with a DLA consume more study time than students with an SLA. Therefore, it is reasonable to suspect that learning approaches and learning duration actually interact in producing academic performance rather than mediating. More specifically, this study aims to: (1) examine the effect of the DLA on learning time-spent and student academic performance and (2) examine the moderation effect of the student learning approach on learning time-spent and academic performance relationship. To achieve those research objectives, this study seeks to answer the following four research questions (RQ), which are: (1) Is there any difference in learning time-spent between students with the DLA and the SLA?; (2) Is there any difference in academic performance between students with the DLA and the SLA?; (3) Is there any effect of learning time-spent on students' academic performance?; and (4) Does the learning approach moderate the effect of learning time-spent on students' academic performance?. The framework of this study is observable in Figure 1.

The following section discusses the research method applied in this study, highlighting the type and instruments used in the research. It also emphasizes using Analysis of Variance (ANOVA) to test RQ 1 and 2, and the MultiGroup Analysis (MGA) to examine RQ 3 and 4, respectively. The subsequent section elaborates on the results and interpretation of data analysis. Finally, the last section remarks on the conclusion and implication of this research.

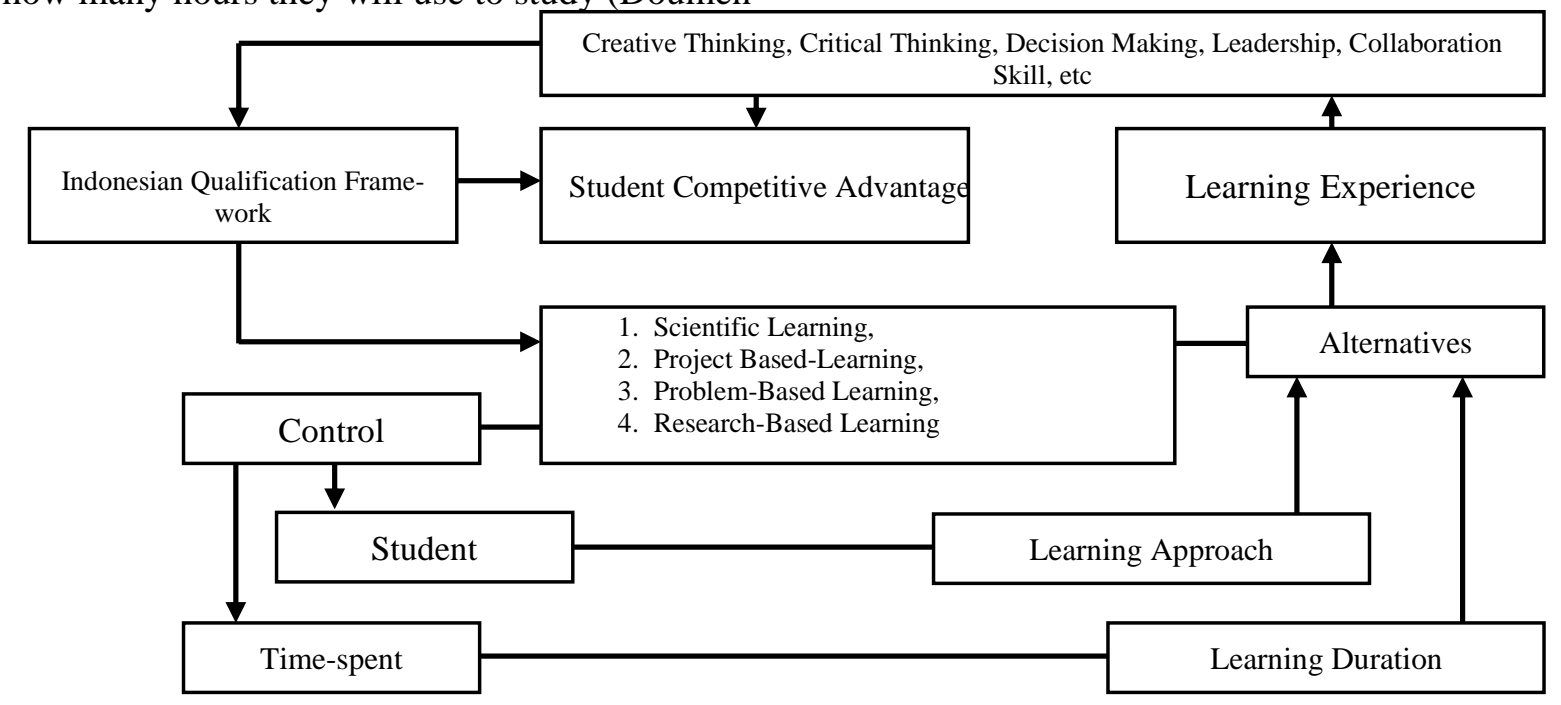

Figure 1. Theoretical Framework 


\section{METHODS}

This research was conducted at the Faculty of Economics, State University of Medan. Indonesia. The subjects of this research were pre-service teacher students in the accounting education major. These students had been taught using an IQF-oriented curriculum with inquiry, scientific, problem, and project-based learning methods. At the time of data collection, the research subjects were in the last year of their study. Therefore, the subjects were expected to represent the respondent's learning style during lectures in response to implementing the IQF-oriented curriculum during the undergraduate education process.

This study used a quasi-experiment method with a field experiment technique (Sekaran \& Bougie, 2016). The treatment was the scientific-based learning implementation, which was mandatory based on the regulation of IQF implementation in higher education curricula. However, this study used sample analysis by separating the students into DLA and SLA groups according to the student's preference to analyze the differences of their learning performance and learning duration during their graduate study (Sekaran \& Bougie, 2016). This study could not control extraneous variables because it collected the data from the field that had previously received the treatment in the whole students mandatorily. However, the researcher collected the data from the whole pre-service students in a single major, accounting education. It was done to control a bias response from different majors and assume that the students experienced a similar learning process in that major.

Table 1. Variables and Instruments

\begin{tabular}{|c|c|c|c|c|}
\hline No & Variable & Definition & Indicators & Source \\
\hline 1 & $\begin{array}{l}\text { Deep Learn- } \\
\text { ing Approach }\end{array}$ & $\begin{array}{l}\text { DLA is a student's } \\
\text { learning approach that } \\
\text { emphasizes in-depth } \\
\text { understanding of the } \\
\text { material in a learning } \\
\text { subject and intrinsically } \\
\text { motivated. }\end{array}$ & $\begin{array}{l}\text { - Satisfaction in learning } \\
\text { - Maximum effort in learning } \\
\text { - Independence in learning } \\
\text { - More study time spent } \\
\text { - High curiosity } \\
\text { - Perseverance in learning } \\
\text { - Able to understand the material com- } \\
\text { - } \text { - Interenst in the subject matter } \\
\text { - Read a lot of recommended literature }\end{array}$ & $\begin{array}{l}\text { Biggs, Kember, } \\
\text { \& Leung (J. } \\
\text { Biggs et al., } \\
\text { 2001) }\end{array}$ \\
\hline 2 & $\begin{array}{l}\text { Surface } \\
\text { Learning Ap- } \\
\text { proach }\end{array}$ & $\begin{array}{l}\text { SLA is a student's } \\
\text { learning approach that } \\
\text { only focuses on memo- } \\
\text { rizing and doing as- } \\
\text { signments because of } \\
\text { fears of not graduating } \\
\text { in a course so that mo- } \\
\text { tivation is formed ex- } \\
\text { trinsically. }\end{array}$ & $\begin{array}{l}\text { - Less of learning efforts. } \\
\text { - Have no enthusiasm for learning } \\
\text { - Learning just for a few things. } \\
\text { - Learning just to specific material that } \\
\text { probably tested } \\
\text { - Learning by memorizing without un- } \\
\text { derstanding the material } \\
\text { - Presuming that lecturers do not expect } \\
\text { maximum learning effort }\end{array}$ & $\begin{array}{l}\text { Biggs, Kember, } \\
\text { \& Leung (J. } \\
\text { Biggs et al., } \\
\text { 2001) }\end{array}$ \\
\hline 3 & Time Spent & $\begin{array}{l}\text { The length of time } \\
\text { spent on students' } \\
\text { learning activities, in- } \\
\text { cluding reading, writ- } \\
\text { ing, and doing lecture } \\
\text { assignments }\end{array}$ & $\begin{array}{l}\text { - Length of time that is used to: } \\
\text { - Learning time inside the class hour } \\
\text { - Reading literature outside class hours } \\
\text { - Writing about lecture material outside } \\
\text { class hours } \\
\text { - Listening to explanations about the } \\
\text { material in the course outside of lec- } \\
\text { ture hours } \\
\text { - Doing exercises assigned by lecturers } \\
\text { or those in learning resources outside } \\
\text { of lecture hours }\end{array}$ & $\begin{array}{l}\text { Everaert et al. } \\
\text { (Everaert et al., } \\
\text { 2017) }\end{array}$ \\
\hline 4 & $\begin{array}{l}\text { Academic } \\
\text { Performance }\end{array}$ & $\begin{array}{l}\text { Academic performance } \\
\text { is the cumulative re- } \\
\text { sults of the learning } \\
\text { process given by the } \\
\text { lecturer. }\end{array}$ & $\begin{array}{l}\text { - GPA of students of the year of entry } \\
2016 \text { in the even semester of the } \\
2019 / 2020 \text { academic year. }\end{array}$ & $\begin{array}{l}\text { Walidaini, } \\
\text { Mukid, Prahu- } \\
\text { tama, \& } \\
\text { Rusgiyono } \\
\text { (Walidaini et al., } \\
\text { 2017) }\end{array}$ \\
\hline
\end{tabular}


Furthermore, this study used some instruments to identify the tendency of students' learning approaches. The trend of learning styles to be observed is DLA and SLA in responding to learning that uses an IQF-oriented curriculum. The instrument was adapted from the R-SPQ-2F instrument (J. Biggs et al., 2001). R-SPQ-2F is a revised instrument of the Study Process Questionnaire (SPQ) developed by Biggs, Kember, \& Leung (J. Biggs et al., 2001), which identifies the type of learning approach used by an individual or group. The R-SPQ-2F consisted of 20 statement items, each of which consisted of 10 items to measure the deep learning approach, and another 10 to measure the surface learning approach. In addition, statements from each of these approaches were divided into statements of motivation and strategies in learning which indicated the respondent's tendency to one learning approach. The instrument was designed with 5 Likert scales to get a figure of learning style tendencies.

Each respondent was asked to fill out the entire questionnaire to measure the DLA and SLA. Identification of learning approach tendencies was made by giving a positive score $(+)$ for the sum score of the DLA variable items and giving a negative score (-) the sum score of the SLA variable items. Thus, if the total sum of the scores of the two approach groups was positive, the respondent belonged to the DLA group. Still, if the result was negative, then the respondent went to the SLA group.

Furthermore, the time-spent was self-reported by responding to the average study hours that students spent a day during their undergraduate education. The learning duration response was examined by researchers in a form of openended questions, so that there was no time frame on the questionnaire that limited responses related to learning duration. A similar technique was also used to get the responses related to the student's GPA. The difference is that GPA is not reported in the form of an estimate because it refers to the transcript documents owned by students. In this study, GPA data were used to represent students' academic performance at their undergraduate level.

Before using the instrument to collect data, the researcher first carried out face validity and conducted pilot tests to the students of the Faculty of Economics in different majors. Face validity involved two experts to correct the layout, readability, and suitability of the content with the extent to which a test would appear to measure what it was intended to measure. Then, after making improvements based on comments about the face validity, a pilot test was carried out with 40 respondents. Both stages were conducted to ensure the validity of the overall instrument items in collecting research data (Cooper et al., 2006; Sekaran \& Bougie, 2016). Variables, definitions, and indicators can be seen in Table 1 .

\section{FINDINGS AND DISCUSSION}

\section{Demography of Sample}

The population consisted of four classes with a total of 109 students. Researchers used a total sampling technique to collect the data. This study used an anonymous questionnaire to avoid response bias, and respondents were asked to fill out the questionnaire voluntarily (Cooper et al., 2006; Sekaran \& Bougie, 2016). From 109 questionnaires distributed, only eighty-six questionnaires were returned and filled in completely. The demographics of the sample can be seen in Table 2 .

Table 2. Demography of Sample

\begin{tabular}{|c|c|c|}
\hline Variable & $\mathbf{n}$ & $\%$ \\
\hline \multicolumn{3}{|l|}{ Gender } \\
\hline Male & 27 & 31 \\
\hline \multirow[t]{2}{*}{ Female } & 59 & 69 \\
\hline & 86 & 100 \\
\hline \multicolumn{3}{|l|}{ Educational Background } \\
\hline Senior High School & 7 & 8 \\
\hline \multirow[t]{2}{*}{ Vocational High School } & 79 & 92 \\
\hline & 86 & 100 \\
\hline \multicolumn{3}{|l|}{ Learning Approach } \\
\hline Deep Learning & 51 & 59 \\
\hline \multirow[t]{2}{*}{ Surface Learning } & 35 & 41 \\
\hline & 86 & 100 \\
\hline \multicolumn{3}{|l|}{ Learning Time-Spent } \\
\hline High & 22 & 26 \\
\hline Moderate & 33 & 38 \\
\hline \multirow[t]{2}{*}{ Low } & 31 & 36 \\
\hline & 86 & 100 \\
\hline
\end{tabular}

\section{Findings}

Data analysis for the first and second research questions used analysis of variance (ANOVA). ANOVA is used to test the difference in time spent and academic performance between groups (Field, 2013). Meanwhile, the third and fourth questions were analyzed using moderated regression with multi-group analysis (MGA). MGA is used because the learning approach as a moderating variable is a categorical variable. Therefore, the accurate moderating analysis tool is to use MGA (Field, 2013; Hair et al., 2009). ANOVA testing and regression analysis in this study used the help of SPSS 25 software while 
MGA was derived from the application of SmartPLS 3.0.

Descriptive Statistics

Descriptive statistics showed that from the eighty-six respondents involved, thirty-five students tend to perceive SLA, and fifty-one students tend to apprehend the DLA. Furthermore, the respondent group with the DLA had a higher average GPA than the respondent group with the SLA. It appeared consistent in the reported minimum and maximum GPA figures. Interestingly, in the time-spent figure, the DLA respondent group reported a unique figure. This group generally had a longer average study time of approximately ten hours per day while the respondent group with the surface learning approach reported an average of approximately seven hours per day. However, the respondent group with the deep learning approach had a relatively high standard deviation of 3,158 , indicating a fairly high variation in the data with four to seventeenth hours in its time-spent. Thus, this figure clearly showed a fairly high gap. Likewise, the figures in this descriptive statistic will be explored further in hypothesis testing as the basis for concluding. Descriptive statistics, in general, can be observed in Table 3.
ANOVA

The result of the ANOVA in this study is presented in table 4 . The result indicates a significant difference in time-spent between groups of respondents with a DLA and an SLA with a pvalue $<0.05$. This finding shows that, in general, students with the DLA tend to have a longer timespent and are significantly different from students with the SLA. This finding confirms the assumptions used by Everaert et al. (2017) in their research that students with DLA tend to consume more time learning and doing assignments. Although respondents had a wide range of variations in time consumption in DLA, in fact, the average time consumption showed a longer duration and had a significant difference. Naturally, students who practiced the DLA needed a lot of time to explore information, discussion, test their arguments with the other colleagues' arguments, built a frame of mind, created work reports, and made presentation documents. DLA-approached students could not pass those various activities without worth of knowledge confirmation (Dolmans et al., 2016; Gordon \& Debus, 2002). Therefore, the learning process tends to be more time-consuming than learning with an SLA.

Table 3. Descriptive of Statistics

\begin{tabular}{lllcccc}
\hline Variable & & N & Mean & Std. Dev. & Min & Max \\
\hline \multirow{3}{*}{ Duration } & Surface Learning & 35 & 7.114 & 1.827 & 5.00 & 13.00 \\
& Deep Learning & 51 & 10.529 & 3.158 & 4.00 & 17.00 \\
& Total & 86 & 9.139 & 3.170 & 4.00 & 17.00 \\
\hline \multirow{3}{*}{ GPA } & Surface Learning & 35 & 3.242 & .117 & 3.00 & 3.68 \\
& Deep Learning & 51 & 3.465 & .187 & 3.15 & 3.89 \\
& Total & 86 & 3.374 & .195 & 3.00 & 3.89 \\
\hline
\end{tabular}

Table 4. Result of ANOVA

\begin{tabular}{|c|c|c|c|c|c|c|c|c|}
\hline \multirow{2}{*}{\multicolumn{2}{|c|}{ Research Question }} & & Sum of Squares & df & Mean Square & $\mathbf{F}$ & Sig. & Decision \\
\hline & & Between Groups & 242.077 & 1 & 242.077 & 33.213 & .000 & \\
\hline \multirow[t]{2}{*}{ RQ1 } & \multirow[t]{2}{*}{ Time Spent } & Within Groups & 612.249 & 84 & 7.289 & & & Supported \\
\hline & & Total & 854.326 & 85 & & & & \\
\hline \multirow{3}{*}{ RQ2 } & \multirow{3}{*}{ GPA } & Between Groups & 1.029 & 1 & 1.029 & 38.818 & .000 & \\
\hline & & Within Groups & 2.226 & 84 & .027 & & & Supported \\
\hline & & Total & 3.255 & 85 & & & & \\
\hline
\end{tabular}

Table 5. Result of Regression Analysis

\begin{tabular}{|c|c|c|c|c|c|c|}
\hline \multicolumn{2}{|c|}{ Research Question } & Coef. & Std. Error & $\mathbf{t}$ & Sig. & Decision \\
\hline RQ3 & Time Spent $\rightarrow$ GPA & .883 & .004 & 17.217 & .000 & Supported \\
\hline \multirow{3}{*}{ RQ4 } & $\begin{array}{l}\text { Time Spent } \rightarrow \text { GPA } \\
(\text { Deep Learning Group) }\end{array}$ & .879 & .005 & 12.881 & .000 & \multirow{3}{*}{ Not Supported } \\
\hline & $\begin{array}{l}\text { Time Spent à GPA } \\
\text { (Surface Learning Group) }\end{array}$ & .670 & .011 & 5.186 & .000 & \\
\hline & Time Spent*Learning Approach $\rightarrow$ GPA & .174 & & 1.429 & .157 & \\
\hline
\end{tabular}


Furthermore, the DLA group's GPA was also significantly different compared to the GPA of the SLA group, with a p-value $<0.05$. This finding shows that students with DLA tend to achieve higher GPAs than those with an SLA. This finding is consistent with the findings of Beattie IV et al. (1997), Gordon and Debus (2002), Dolmans et al. (2016), and Everaert et al. (2017), which revealed that prospective teachers who practiced the DLA had better self-efficacy and academic performance, especially in learning and assessment programs that demand holistic knowledge within students (Beattie IV et al., 1997; Gordon \& Debus, 2002; Korthagen, 2004). In this study, respondents were faced with an inquiry-based learning program and a scientific approach (Bensley \& Murtagh, 2012; Hall et al., 2004; Reif, 1981). Thus, students are required to explore and construct their own knowledge. In such situations, students have autonomy in determining their learning strategies with minimal intervention from the lecturer (Bruner, 1996; Vygotsky, 1978). Therefore, the practice of a DLA is increasingly needed by learners themselves.

\section{Regression Analysis}

Regression analysis in this study was carried out in two stages: (1) testing the effect of time spent on academic performance, and (2) testing the moderation of the learning approach on the relationship of time spent on academic performance. The test was carried out in two stages because the moderation analysis in this study used Multi-Group Analysis (MGA). Thus, in the first test, all sample data were used. Meanwhile, in the second test, the sample data were separated into the DLA group and the SLA group. The results of those two tests can be observed in table 5. The first test results showed that the time spent had a positive and significant effect on the student academic performance with a regression coefficient of 0.453 and a p-value of $0.000(<0.05)$. This finding is in line with previous research done by Opdecam \& Everaert (2018), Hattie (2015), Doumen et al. (2014), and Evereart et al. (2017), which suggests that students who spend more time studying and doing assignments tend to show better academic performance and achievement. In addition, students who consumed more learning time have the possibility to absorb more information, especially in constructivism learning which requires students to explore a wide range of learning resources and construct knowledge collaboratively with their peers
(Pande \& Bharathi, 2020). These processes, in addition to consuming a lot of learning time, also provide a solid learning experience and, in turn, result in good academic performance.

To deepen the three previous findings, this study examines the moderating effect of the students' learning approach on the value of time spent on students' academic performance. When tested separately between groups, the regression coefficient of the effect of time spent on academic performance of the DLA group showed a greater number of coefficients than the SLA group with regression coefficients of 0.879 and 0.670 , respectively. Both regression coefficients were found to have a significant level with a pvalue $<0.05$. However, when further tested using MGA to examine the significance of the difference in influence between the two groups, it was found that there was no significant moderating effect of the learning approach with a p-value of 0.157 (>0.05). These results indicated no interaction between the students' learning approach and the time they consume in influencing their academic performance. This study is slightly different from Evereart et al. (2017), who reviewed time spent as a mediator of the influence of the DLA on academic performance. However, this study still enriched the learning-related research to the effect of the learning approach and time spent on academic performance. On the one hand, both the learning approach and the time spent have a positive effect on academic performance separately although various other studies have indicated that the deep learning approach tends to result in higher time consumption (Dolmans et al., 2016; Everaert et al., 2017; Gordon \& Debus, 2002). Likewise, for the case in this research, the instructional design and evaluation provided actually required students to practice a DLA (Beattie IV et al., 1997; Dolmans et al., 2016; Gordon \& Debus, 2002). However, as explained earlier, students had autonomy over their own learning activities, so that it was still possible for them to practice surface learning even though the lecturers taught with inquiry, scientific, problem-based, and project-based approaches (Dolmans et al., 2016; Lange \& Mavondo, 2004; Lucas, 2001). As a result, both students who practiced deep learning and surface learning had a fairly wide learning time span, and in fact, the time spent had a high significant influence in both groups. Therefore, the treatment that lecturers can give to optimize learning activities through these two aspects must be done separately or using a different stimulus. 


\section{Discussion}

The Government of the Republic of Indonesia, through Government Regulation No. 32 of 2013 concerning National Educational Standard and the Regulation of the Minister of Education and Culture no. 3 of 2020 concerning National Standards for Higher Education, obliges all stakeholders at a university level to educate students to have mastery at three different areas, namely, attitudes, knowledge, and expertise which can contribute to critical thinking and problem-solving skill in their field. The graduates should be able to connect all different kinds of knowledge that promote problem-solving and collaborate with multidisciplinary and multicultural teams. It demands the universities to transform the learning process to use scientific, problem, and project-based learning. Theoretically, it should take the student to the long, varied, and demanding learning process, which leads students to practice DLA in their learning activities (Dinsmore \& Alexander, 2012; Dolmans et al., 2016; Salamonson et al., 2013). At the same time, students who practice DLA will effectively gain conceptual and analytical skills due to their learning experience (Hall et al., 2004).

In fact, the current study found that there were still a number of students who practiced surface learning even the universities had demanded that students should engage in the rich and complex learning process. Such conditions made the researchers do further analysis to understand more on how the DLA would fit to students while pursuing their academic performance. The results of data analysis revealed that: (1) students who used the DLA spent higher learning time than those employing the SLA; (2) students who preferred the DLA showed better academic performance than those using the SLA; (3) time spent had a positive and significant effect on students' academic performance; and (4) learning approaches did not moderate the effect of learning duration on student academic performance. The final finding shows that undergraduate students had a long learning time spent, and it affected their academic performance even though basically these students had different learning orientations. While the learning orientation represented by DLA and SLA had something to do with the time spent on the learning and academic performance, it did not interrelate with the time spent in students' academic performance. This is presumably because, in nature, whether using DLA or SLA, the consumption of student learning time, in general, was quite high because the used learning methods were inquiry, scientific, problem, and project approaches.

Implementing a scientific approach to teaching the pre-service teacher students placed them to engage in complex learning processes, including reading, discussion, problem-solving, mini-research, and project. Therefore, it would naturally require some amount of time that students need to spend. However, student learning preference, which separated them into DLA or SLA learners, also shows different time consumption during learning. DLA learners tend to flow in their learning process during completing assignments. They tend to have a curiosity to explore more information to understand some framework comprehensively. That flowing experience gave students impression to enjoy their learning process, resulting in longer time-spent compared with those who employed SLA during their learning process. In contrast, SLA students who were found result-oriented had no responsive interests in exploring the depth of the materials, project-based issues, and wider knowledge related to their field of stud. SLA students merely focused on task completion, so that their need shorter time consumption.

Furthermore, in consistence with some previous research, this study shows that DLA students had better academic performance than SLA students. Educational scientists argue that the commitment of DLA students to their learning activity is developed by intrinsic motivation (Everaert et al., 2017; Lange \& Mavondo, 2004; Lucas, 2001). Students with high intrinsic motivation tend to use learning as an instrument to provide personal satisfaction that enriches their quality, so that they tend to drive themselves in deep learning. In addition, students with intrinsic motivation tend to be passionate about learning and orient themselves to the learning process (Lange \& Mavondo, 2004). Conversely, students who took learning as a path to achieve grades place extrinsic motivation as a trigger for learning (Everaert et al., 2017; Lange \& Mavondo, 2004). SLA students carried out learning activities only when they needed the activities for assignment completion. They were not fully interested in exploring wider scopes in terms of their personal knowledge satisfaction. It eventually led to the fact that the learning process would empirically impact students' knowledge and skills mastery.

Regarding mastery of knowledge in the long term and the ability to apply knowledge to actual problems in real work activities, SLA 
students will have difficulty (J. Biggs et al., 2001; Everaert et al., 2017). The main problem is not only in their knowledge and skill mastery but also in their weak learning culture. The cultivation of learning characters in DLA will carry over to their daily work activity. Therefore, universities must determine a more rigorous and measurable strategy to control students' learning practices, so that they tend to have a DLA. Indeed, the challenge is complex because preparing students with competence in problem-solving and critical thinking adaptive to the time is not an easy and simple matter (Dolmans et al., 2016).

The current study also found that students' time spent learning and doing assignments contributed to their academic achievement. The autonomy of students to allocate their time when learning appeared in a wide range. The time spent they used reflected a piece of information related to academic performance. The cost of time that students commit to spent empirically proved the theory that students who spend more time learning will gain academic success (Hattie, 2008; Opdecam \& Everaert, 2018). With a longer learning time, students can collect and understand more information, do more assignments, discuss more issues, and solve more problems. Students in similar groups showed the variation of time consumption in the learning activity, either DLA or SLA (Doumen et al., 2014; Everaert et al., 2017). Thus, the researcher assumed that students would also present different academic performances. Therefore, the influence of the student's learning approach should be analyzed further by considering its interaction with time-spent to influencing academic performance.

In the final stage, this study analyzed the moderating effect of students' learning approach on the relationship of time spent and student academic performance. Although the learning approach affected learning time spent and academic performance, the main background for forming the time spent and the learning approach was not the same. Therefore, it is probably made the learning approach had not interaction to improve students' academic performance. Basically, all students had to spend much time finishing their learning obligation and assignment because of the implementation of the scientific approach. However, there were many strategies that students could use as the alternatives. That condition resulted in a wide range of learning time consumption. On the other hand, the learning approach, DLA and SLA, became the preferences embedded in the student's way of thinking.
Therefore, some teaching approaches might not be dissonant, so that students will be practicing it almost in every condition.

Those findings mentioned finally came to the idea that higher education level need to evaluate and strategically prepare their instructional design a way better than before. Implementing scientific, problem, and project-based learning itself cannot guarantee students will allow themselves to deeply interact and structurally construct new knowledge. According to Vygotsky's social cognitive theory, learning design cannot be simply task-based. Still, task assignments must consider various learning joints to produce a social framework that can influence student learning practices (Vygotsky, 1978). Therefore, there is a complex issue that lecturers should deal with to successfully implement scientific, problem, and project-based learning, which stand on the constructivism approach (Bruner, 1996; Vygotsky, 1978). The constructivism approach seeks to design the learning environment in such a way as to be able to lead students to achieve their learning goals (Bada \& Olusegun, 2015; Bensley \& Murtagh, 2012; Pande \& Bharathi, 2020; Schunk, 2012). The learning environment is relevant literature, projects, group work, cooperative learning, cases, exercises, brainstorming, mini-research, and various other instruments whose outcome is the mastery of knowledge following predetermined standard qualifications (Bensley \& Murtagh, 2012; Christensen et al., 2019; Dolmans et al., 2016; Opdecam \& Everaert, 2018; Pande \& Bharathi, 2020; Sagala \& Effiyanti, 2019). The important point drawn from the results of the study is that the learning environment requires students to play an active role as both learners and practitioners, which later provide them some opportunities to confirm their initial knowledge with the new knowledge they gain from the fundamental theory, research results, and actual practices (Dejene et al., 2018; Dolmans et al., 2016; Sagala \& Effiyanti, 2019). Learning process helping student to constructs new comprehensive understanding and give them learning experiences that teach them how to master new knowledge (Dolmans et al., 2016; Dunne \& Martin, 2006; Pande \& Bharathi, 2020; Scheer et al., 2012; Von Glasersfeld, 1998).

Additionally, both a university and its teaching staffs should carefully understand that the learning process is a continuing process that progressively develop according to the dynamics of students, and it must be generated from deep reflection, not just based on simple technical 
rationality (Blumenfeld et al., 1991; Reif, 1981; Schunk, 1987). In other words, the university must further explore holistic learning designs in practicing inquiry, scientific, problem, and project-based approaches. At the same time, the lecturers must take an important role in developing learning that instills a scientific mindset in students. Assignments given to students to demand problem solving and project development must be followed by the availability of guidance, readiness to provide feedback, availability of literature, accessibility to information, the sensitivity of lecturers in capturing learning problems, the readiness of lecturers to provide alternative solutions to learning problems, and readiness of lecturers to interact continuously with students even outside of study hours. Preparing a learning environment that can help and stimulate students to learn to achieve learning goals is a complex and complicated matter (Blumenfeld et al., 1991; Christensen et al., 2019; Dejene et al., 2018; Schunk, 2012). This challenge certainly has big implications in evaluating learning practices and human resource development for academic staff in higher education.

\section{CONCLUSION}

This study aims to: (1) examine the effect of the deep learning approach on student learning time spent and academic performance, and (2) examine the moderation of the student learning approach to learning time spent on student academic performance. This study found that the DLA affected student learning duration and academic performance but did not moderate the effect of time spent on student academic performance. Theoretically, this study adds an insight related to the basic background of the students' learning orientation, which promoted learning actions with a certain approach. Meanwhile, the length of time spent for learning was indeed formed from the demands of the learning process and heavy assignments. Based on these findings, optimizing student learning was the DLA stimulus through the implemented learning program.

Practically, the findings of this study recommend universities to evaluate learning programs and assignments that have been held to prepare students according to the Indonesian Qualification Framework (IQF) qualifications. The existing learning programs have not completely stimulated students to use a deep learning approach in completing their tasks and their learning process. Furthermore, developing a more careful and holistic learning program targeting various aspects of student learning is necessary. Lecturers must stimulate students to learn and apply a deep learning approach in their learning activities both inside and outside the classroom. Thus, the learning experience and learning orientation will be embedded in students and become their provisions for a career in the future.

This study has several limitations, including the limited variety of respondents to the Faculty of Economics students. The limitations on the observed learning design are the existing learning practices after the implementation of the IQF. The next researcher can review the phenomenon of respondents with more diverse backgrounds and further review what kind of learning designs can really stimulate deep learning for students. In addition, future studies can use pure experimentation to determine what determinant variables are the key to the deep learning approach.

\section{ACKNOWLEDGEMENTS}

This research was funded by the fundamental research grant of PNBP Universitas Negeri Medan year 2021.

\section{REFERENCES}

Bada, S. O., \& Olusegun, S. (2015). Constructivism learning theory: A paradigm for teaching and learning. Journal of Research \& Method in Education, 5(6), 66-70.

Beattie IV, V., Collins, B., \& McInnes, B. (1997). Deep and surface learning: a simple or simplistic dichotomy? Accounting Education, 6(1), 1-12.

Bensley, D. A., \& Murtagh, M. P. (2012). Guidelines for a scientific approach to critical thinking assessment. Teaching of Psychology, 39(1), 5-16.

Biggs, J. B. (1987). Student Approaches to Learning and Studying. Research Monograph. ERIC.

Biggs, J., Kember, D., \& Leung, D. Y. P. (2001). The revised two-factor study process questionnaire: R-SPQ-2F. British Journal of Educational Psychology, 71(1), 133-149.

Blumenfeld, P. C., Soloway, E., Marx, R. W., Krajcik, J. S., Guzdial, M., \& Palincsar, A. (1991). Motivating project-based learning: Sustaining the doing, supporting the learning. Educational Psychologist, 
26(3-4), 369-398.

Bruner, J. S. (1996). The culture of education. Harvard University Press.

Chotitham, S., Wongwanich, S., \& Wiratchai, N. (2014). Deep learning and its effects on achievement. Procedia-Social and Behavioral Sciences, 116, 3313-3316.

Christensen, J., Harrison, J. L., Hollindale, J., \& Wood, K. (2019). Implementing teambased learning (TBL) in accounting courses. Accounting Education, 28(2), 195-219.

Cooper, D. R., Schindler, P. S., \& Sun, J. (2006). Business Research Method. McGraw-Hill.

Dejene, W., Bishaw, A., \& Dagnew, A. (2018). Preservice teachers' approaches to learning and their teaching approach preferences: Secondary teacher education program in focus. Cogent Education, 5(1), 1502396.

Dinsmore, D. L., \& Alexander, P. A. (2012). A critical discussion of deep and surface processing: What it means, how it is measured, the role of context, and model specification. Educational Psychology Review, 24(4), 499-567.

Dolmans, D. H. J. M., Loyens, S. M. M., Marcq, H., \& Gijbels, D. (2016). Deep and surface learning in problem-based learning: a review of the literature. Advances in Health Sciences Education, 21(5), 1087-1112.

Doumen, S., Broeckmans, J., \& Masui, C. (2014). The role of self-study time in freshmen's achievement. Educational Psychology, 34(3), 385-402.

Dunne, D., \& Martin, R. (2006). Design thinking and how it will change management education: An interview and discussion. Academy of Management Learning \& Education, 5(4), 512-523.

Everaert, P., Opdecam, E., \& Maussen, S. (2017). The relationship between motivation, learning approaches, academic performance and time spent. Accounting Education, 26(1), 78-107.

Field, A. (2013). Discovering statistics using IBM SPSS statistics. sage.

Gordon, C., \& Debus, R. (2002). Developing deep learning approaches and personal teaching efficacy within a preservice teacher education context. British Journal of Educational Psychology, 72(4), 483511.

Hair, J. F., Black, W. C., Babin, B. J., \& Anderson, R. E. (2009). Multivariate Data Analysis 7th Edition Pearson Prentice Hall.

Hall, M., Ramsay, A., \& Raven, J. (2004). Changing the learning environment to promote deep learning approaches in firstyear accounting students. Accounting Education, 13(4), 489-505.

Hattie, J. (2008). Visible learning: A synthesis of over 800 meta-analyses relating to achievement. routledge.

Hattie, J. (2015). The applicability of visible learning to higher education. Scholarship of Teaching and Learning in Psychology, 1(1), 79-91.

Korthagen, F. A. J. (2004). In search of the essence of a good teacher: Towards a more holistic approach in teacher education. Teaching and Teacher Education, 20(1), 77-97.

Lange, P. de, \& Mavondo, F. (2004). Gender and motivational differences in approaches to learning by a cohort of open learning students. Accounting Education, 13(4), 431-448.

Lucas, S. R. (2001). Effectively maintained inequality: Education transitions, track mobility, and social background effects. American Journal of Sociology, 106(6), 1642-1690.

Marton, F., \& Säljö, R. (1976). On qualitative differences in learning: I-Outcome and process. British Journal of Educational Psychology, 46(1), 4-11.

Opdecam, E., \& Everaert, P. (2018). Seven disagreements about cooperative learning. Accounting Education, 27(3), 223-233.

Pande, M., \& Bharathi, S. V. (2020). Theoretical foundations of design thinking--A constructivism learning approach to design thinking. Thinking Skills and Creativity, 36, 100637.

Reif, F. (1981). Teaching problem solving-A scientific approach. The Physics Teacher, 19(5), 310-316.

Sagala, G. H., \& Effiyanti, T. (2019). SMEs project: a method to encourage interpersonal skills among pre-service 
accountant. Journal of Applied Research in Higher Education.

Salamonson, Y., Weaver, R., Chang, S., Koch, J., Bhathal, R., Khoo, C., \& Wilson, I. (2013). Learning approaches as predictors of academic performance in first year health and science students. Nurse Education Today, 33(7), 729-733.

Scheer, A., Noweski, C., \& Meinel, C. (2012).

Transforming constructivist learning into action: Design thinking in education. Design and Technology Education: An International Journal, 17(3).

Schunk, D. H. (1987). Peer models and children's behavioral change. Review of Educational Research, 57(2), 149-174.

Schunk, D. H. (2012). Learning theories: An educational perspective. Pearson.
Sekaran, U. S., \& Bougie, R. J. (2016).

Research Methods For Business : A Skill Building Approach (7th ed.). John Wiley $\&$ Sons Inc.

Von Glasersfeld, E. (1998). Cognition, construction of knowledge, and teaching. In Constructivism in science education (pp. 11-30). Springer.

Vygotsky, L. S. (1978). Socio-cultural theory. Mind in Society, 6, 52-58.

Walidaini, N., Mukid, M. A., Prahutama, A., \& Rusgiyono, A. (2017). Analisis

Diskriminan Berganda Dengan Peubah Bebas Campuran Kategorik dan Kontinu Pada Klasifikasi Indeks Prestasi Kumulatif Mahasiswa. Media Statistika, 10(2), 71-83. 